\title{
FOUR NEW SPECIES OF PLEUROTHALLIS (ORCHIDACEAE: PLEUROTHALLIDINAE) FROM THE VALLE DEL CAUCA DEPARTMENT IN COLOMBIA
}

\author{
Adam P. Karremans ${ }^{1,2,5}$, Lizeth Rodríguez-MartíneZ ${ }^{3,4}$ \& Cristian Rincón-Useche ${ }^{3}$ \\ ${ }^{1}$ Lankester Botanical Garden, University of Costa Rica, P.O. Box 302-7050 Cartago, Costa Rica. \\ ${ }^{2}$ Naturalis Biodiversity Center, Leiden, The Netherlands. \\ ${ }^{3}$ Universidad Nacional de Colombia, Sede Palmira, Facultad de Ciencias Agropecuarias; Grupo de \\ Investigación en Recursos Fitogenéticos Neotropicales (GIRFIN). \\ ${ }^{4}$ Grupo de Investigación de Sistemática y Evolución de Gimnospermas y Angiospermas Neotropicales, \\ Universidad Nacional de Colombia, sede Bogotá. \\ ${ }^{5}$ Author for correspondence: adam.karremans@ucr.ac.cr
}

\begin{abstract}
Pleurothallis indecora, P. juvenilis, P. lueriana and P. queremalensis are described from material collected in the municipality of Dagua, department of Valle del Cauca, Colombia. The four species were found during field inventories of the Orchidaceae in San José del Salado and El Queremal, they are illustrated, and a comparison with their closest relatives is provided.
\end{abstract}

Key words: El Queremal, Pleurothallis indecora, P. jimii, P. juvenilis, P. lueriana, P. queremalensis, San José del Salado

Introduction. The department of Valle del Cauca is located in the south-western part of Colombia. Even though it represents less than two percent of the country's territory, the complexity of its mountainous system allows for a high diversity of microhabitats that has prompted species richness and endemism. This high diversity undoubtedly extends to the Orchidaceae family, and many additional novelties are surely to appear in the coming years with increased knowledge and research efforts in this and other Colombian departments.

During field inventories of the Orchidaceae of San José del Salado and El Queremal, in Dagua Municipality, in Valle del Cauca, Colombia, four undescribed species of Pleurothallis R.Br. were found. These novelties follow those previously described from the same area by Pérez-Escobar, Kolanowska \& Rincón-Useche (2013), Rodríguez-Martínez and Blanco (2015), Hágsater, Reina-Rodríguez and Rodríguez-Martínez (2015), Rodríguez-Martínez, Rincón-Useche and Karremans (2015), and Hágsater, Santiago Ayala and Rodríguez-Martínez (2016).

Two of the new species belong to a group of species placed in Pleurothallis subgen. Ancipitia Luer (Luer 1986, 1989), a third within the very closely allied Pleurothallis subgen. Scopula Luer (Luer 1986, 1989), and the fourth to Pleurothallis sect. Pleurothallis subsect.
Macrophyllae-Racemosae (Lindl.) Luer (Luer 1999). The four Pleurothallis species are described here-forth.

\section{TAXONOMIC TREATMENT}

Pleurothallis indecora Rodr.-Mart. \& Karremans, sp. nov. (Fig. 1, 5a).

TYPE: Colombia. Valle del Cauca: Dagua, San José del Salado, remnant cloud forests at 1850 m elevation, temperature $20^{\circ} \mathrm{C}$. September 21, 2012, L. RodríguezMartínez \& C. Rincón-Useche 084 (holotype: COL!).

Diagnosis: Pleurothallis indecora is similar to $P$. driessenii Luer but distinguished by the larger plants with longer ramicauls, the pale green flowers (vs. yellowish, minutely flecked with light purple), the narrowly oblong-lanceolate (vs. oblong-obovate) petals, and the broadly ovate (vs. obovate) lip with slightly elevated (vs. erect) sides and entire (vs. irregular) margins.

Plant epiphytic, herbaceous, erect, up to $20 \mathrm{~cm}$ tall; roots flexuous, thin, less than $1 \mathrm{~mm}$ in diameter. Ramicaul erect, thin, four-angled, up to $15 \mathrm{~cm}$ long, covered by tubular papyraceous bracts close to the base, 2.0-2.5 cm long. Leaf sub-erect, sessile, coriaceous, ovate, acute, $3.5-5.0 \times 1.3-2.0 \mathrm{~cm}$. Inflorescence a sub- 


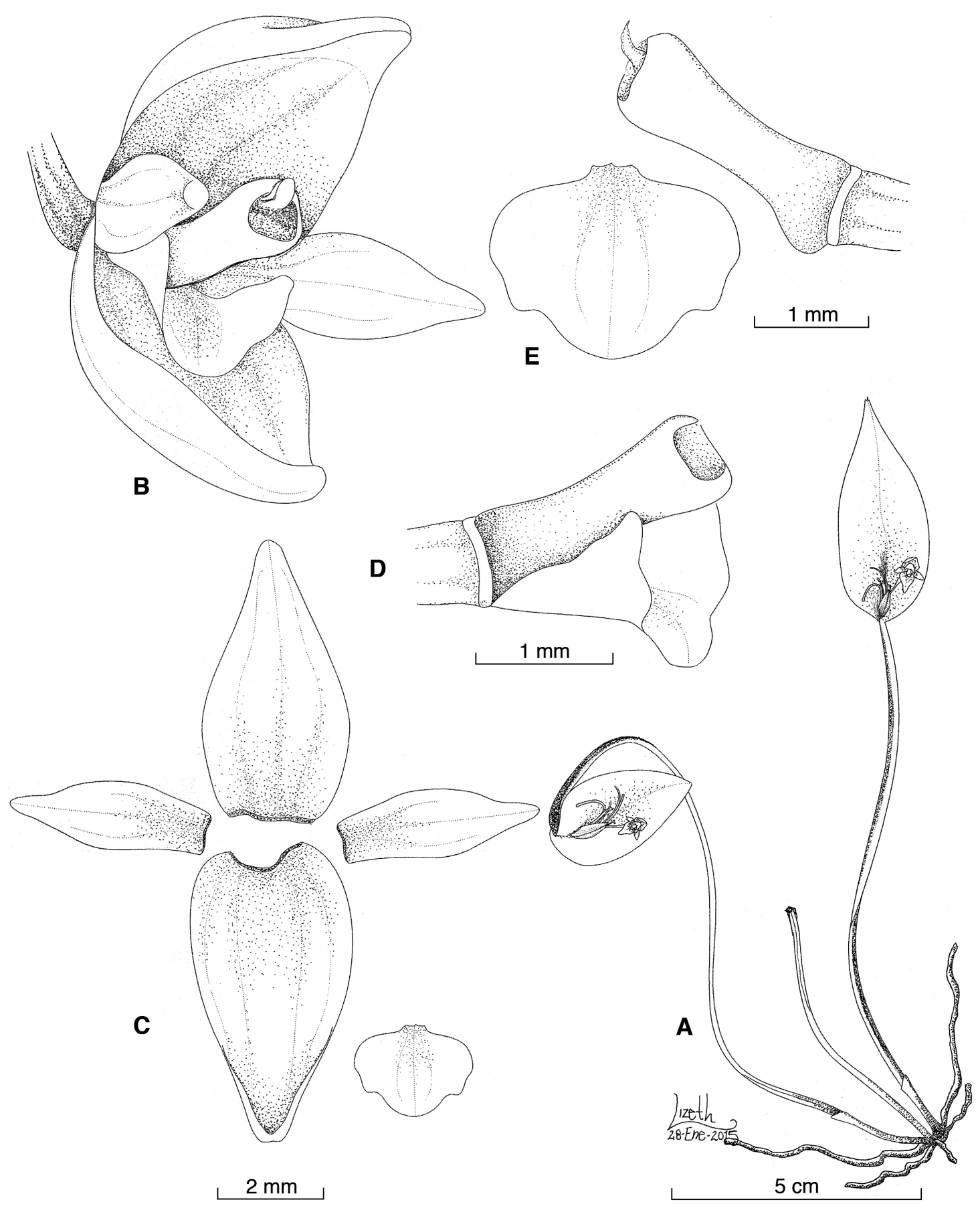

Figure 1. Pleurothallis indecora Rodr.-Mart. \& Karremans. A. Habit. B. Flower. C. Dissected perianth. D. Column and lip in lateral view. E. Column and lip relative to each other. Illustration by L. Rodríguez-Martínez based on the holotype.

fascicle of successive, single-flowered peduncles, bract of the inflorescence 7-9 mm long; peduncle 3-4 mm long, pedicels 10-15, persistent, $1.0-1.3 \mathrm{~cm}$ long, floral bracts 2, 2-3 mm long; flowers pale green, sepals not spreading widely, the dorsal sepal ovate, obtuse to subacute, 3-veined, 5.0-5.5 × 2.5-3.0 mm; lateral sepals 
fully fused into a concave, ovate, obtuse synsepal, 4-veined, 5.0-5.5 ×3.0-3.5 mm; petals narrowly oblonglanceolate, acute, 3-veined, 3.5-4.0 × 1.0-1.5 mm; lip broadly ovate to sub-orbicular, shallowly trilobate, obtuse, margin entire, articulate to the column foot, $1.5-1.8 \times 2.0-2.3 \mathrm{~mm}$, midlobe broadly hemielliptic, obtuse, lateral lobes slightly elevated, broadly ovatehemielliptic, irregular; column terete, with a short column foot, $2.0-2.4 \times 0.8-0.9 \mathrm{~mm}$. Anther and stigma apical; rostellum conspicuous, triangular; pollinia 2, narrowly ovoid, joint by a drop-like viscidium.

Eтymology: The name comes from the Latin indecorus "without decoration" in reference to the simplicity of the flower both in color and shape.

Distribution and ECOlogy: This species is known only from the mountains around San José del Salado, Dagua municipality, in the Valle del Cauca, Colombia, at elevations around $1900 \mathrm{~m}$. It is found as an epiphyte in the cloud forests on the occidental mountain range. Both specimens were found growing on Tibouchina sp. (Melastomataceae).

Pleurothallis indecora belongs to the Ancipitia Luer group and can be recognized by the four-angled ramicauls, the short, ovate leaves, the numerous subfascicled inflorescences, and especially the greenish, inornate flowers. It is similar to the Ecuadorian endemic P. driessenii Luer but distinguished by the larger plants with longer ramicauls (10-15 cm vs. 5-6 cm long), the pale green flowers (vs. yellowish, minutely flecked with light purple), the narrowly-elliptic (vs. oblongobovate) petals, and the broadly ovate (vs. obovate) lip with slightly elevated (vs. erect) sides and entire (vs. irregular) margins. The Peruvian $P$. neodubbeldamii J.M.H.Shaw is also somewhat similar, but is easily distinguished by the sub-ancipitous ramicauls with elliptical leaves, the elliptical sepals, the semiterete linear petals, and the thick subapical callus of the lip.

Pleurothallis juvenilis Rodr.-Mart. \& Karremans, sp. nov. (Fig. 2, 5b).

TYPE: Colombia. Valle del Cauca: Dagua, San José del Salado, remnant cloud forests at $1850 \mathrm{~m}$ elevation, temperature $20^{\circ} \mathrm{C}$. December 6, 2014, L. RodríguezMartínez 275 (holotype: VALLE!).
Diagnosis: The habit of $P$. juvenilis is reminiscent of P. cosmetron Luer and P. silverstonei Luer, it can be easily distinguished from the first by the obtuse sepals (vs. acute, long-acuminate), the broad, elliptic-obovate, sub-acuminate petals (vs. ovate, long-acuminate), and the column the protrudes beyond the lip apex (vs. column much shorter than the lip). From the second, which is likely to be its closest relative, $P$. juvenilis is distinguished by the sub-acuminate petals (vs. acuteacuminate), and especially by the much shorter lip that does not extend beyond the column (vs. at least double the column length).

Plant epiphytic, herbaceous, erect, up to $40 \mathrm{~cm}$ tall; roots flexuous, thin, below $0.5 \mathrm{~mm}$ diameter, densely fasciculate. Ramicaul erect, thin, four-angled, up to 25 $\mathrm{cm}$ long, covered by tubular papyraceous bracts close to the base 4-5 cm long; leaf green sometimes suffused with purplish, sub-erect, sessile, broadly-elliptic, acute, apiculate, and with a small mucron, 8-14 × 3-6 $\mathrm{cm}$. Inflorescence a sub-fascicle of successive, singleflowered peduncles, born from a 7-9 $\mathrm{mm}$ long bract, and emerging close to middle of the leaf, suberect, subequal to the leaf; peduncle 3-4 mm long, pedicels $50-80$, persistent, $2-3 \mathrm{~cm}$ long, floral bracts $2-3 \mathrm{~mm}$ long; flowers cream to pale yellow with small purplish to pinkish spots, successive, up to at least 3 open at once; dorsal sepal sub-erect, concave, ovate, obtuse to sub-acute, 3-veined, 5.0-5.5 × 2.5-3.0 mm; lateral sepals fully fused into a synsepal, concave, ovateelliptic, obtuse, slightly constricted near the apex, 4-veined, $5.0-5.5 \times 3.0-3.5 \mathrm{~mm}$; petals pale yellow with small pinkish spots, elliptic to obovate, acute, sub-acuminate, $3.5-4.0 \times 1.0-1.5 \mathrm{~mm}$; lip yellowish suffused with pink, sub-trapezoid, trilobate, articulate to the column foot, $2.5-2.8 \times 2.0-2.3 \mathrm{~mm}$, midlobe slightly recurved, broadly ovate, truncate, obtuse, lateral lobes erect, broadly ovate-hemielliptic, obtuse; column whitish suffused with pink apically, terete, slightly arched upwards above the middle, protruding well beyond the lip apex, with a short column foot, 2.0-2.4 × 0.8-0.9 mm; anther cap apical; stigma apical with a conspicuous, triangular rostellum; pollinia 2 , narrowly ovoid, joint by a drop-like viscidium.

Etymology: From the Latin juvenilis, youthful, in allusion to the discrete, pale flowers fully covered by minuscule pinkish spots, as if the face of an introvert youth. 

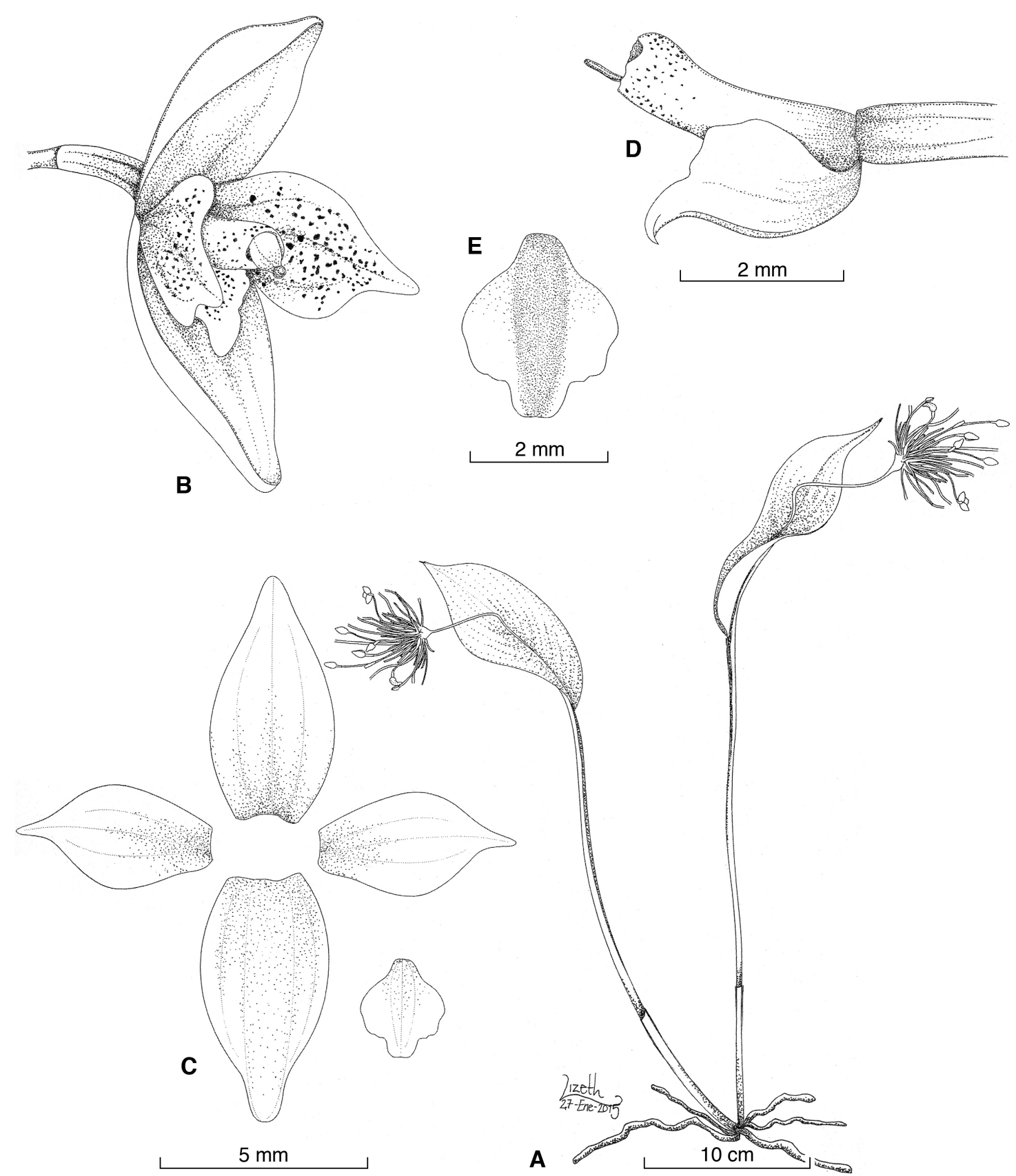

Figure 2. Pleurothallis juvenilis Rodr.-Mart. \& Karremans. A. Habit. B. Flower. C. Dissected perianth. D. Column and lip in lateral view. E. Lip. Illustration by L. Rodríguez-Martínez based on the holotype.

Additional specimens: Colombia. Valle del Cauca: Dagua, San José del Salado, remnant cloud forests at $1850 \mathrm{~m}$ elevation, temperature $20^{\circ} \mathrm{C}$. December 6 , 2014, L. Rodríguez-Martínez 276 (COL!). San José del Salado, remnant cloud forests at 1850 m elevation, temperature $20^{\circ} \mathrm{C}$. March 3, 2014, L. RodríguezMartínez \& C. Rincón-Useche 208 (CUVC!). San José del Salado, remnant cloud forests at 1850 m elevation, temperature $20^{\circ} \mathrm{C}$. Jun 10,2013 , L. RodríguezMartínez \& C. Rincón-Useche 114 (COL!). 
Distribution AND ECOLOGY: It is known from the mountains around San José del Salado, Dagua municipality, in the Valle del Cauca, Colombia, at elevations around $1900 \mathrm{~m}$. It is found as an epiphyte in the cloud forests on the western Andes, were it can grow on Tibouchina sp. (Melastomataceae). Found in bloom in March, June and December.

The main feature used to set aside species of Pleurothallis subgen. Scopula has been the emergence of the inflorescence well above the leaf base. In most species the inflorescence emerges close to the apex of the narrow leaf, In Pleurothallis juvenilis the congested, subfascicled inflorescence emerges from the middle of a broad leaf. Such a habit is found in two other species, $P$. cosmetron Luer and P. silverstonei Luer. The latter is most likely the closest relative of $P$. juvenilis, but the new species can be distinguished the sub-acuminate petals (vs. acute-acuminate), and especially by the much shorter lip (1.5-1.8 vs. $6 \mathrm{~mm}$ long) that does not extend beyond the column (vs. at least double the column length). From $P$. cosmetron it is easily distinguished by the obtuse sepals (vs. acute, long-acuminate), the broad, elliptic, shortly apiculate petals (vs. ovate, longacuminate), and the column the protrudes beyond the lip apex (vs. column much shorter than the lip).

\section{Pleurothallis lueriana Karremans \& Rodr.-Mart., sp. nov. (Fig. 3, 5c).}

TYPE: Colombia. Valle del Cauca: Dagua, El Queremal, remnant cloud forests at $1600 \mathrm{~m}$ elevation, temperature $24^{\circ} \mathrm{C}$. August 10, 2014, L. RodríguezMartínez 220 (holotype: COL!).

Diagnosis: Amongst the species of Pleurothallis subgen. Ancipitia, P. lueriana is immediately distinguished by the thick, dark purple, obtrapezoid lip, with erect lateral lobes, and the pair of apical, retrorse, arm-like lobes on the column. The lip and column of P. membracidoides Luer are somewhat similar, but the new species can be easily distinguished by the pubescent petals (vs. glabrous), the fully dark purple lip (vs. basally purple, and yellow-white above the middle) with a conspicuously warty apex along the lateral lobes (vs. inornate lateral lobes) and the conspicuous, pubescent, arm-like lobes near the apex of the column (vs. inconspicuously lobed, non-pubescent).
Heterotypic Synonyms: Pleurothallis jimii Luer, Mongr. Syst. Bot. Missouri Bot. Gard. 95: 237. 2004, nom. inval. Ancipitia jimii (Luer) Luer, Mongr. Syst. Bot. Missouri Bot. Gard. 95: 254. 2004, nom. inval. Elongatia jimii (Luer) Luer, Harvard Pap. Bot. 17: 368. 2012, nom. inval.

Plant epiphytic, herbaceous, erect, up to $30 \mathrm{~cm}$ tall; roots flexuous, thin, $0.5-1 \mathrm{~mm}$ diameter, densely fasciculate. Ramicaul erect, thin, laterally compressed, ancipitous, up to $10-17 \mathrm{~cm}$ long, covered by tubular papyraceous bracts close to the base, up to $3-5 \mathrm{~cm}$ long; leaf sub-erect, sessile, coriaceous, broadlyelliptic, mucronate, 8-11 × 1-3 cm. Inflorescence a sub-fascicle of successive, single-flowered peduncles; pedicels 5-10, persistent, $4.0-4.5 \mathrm{~cm}$ long, floral bracts 2, 5-7 mm long; ovary $4.5 \mathrm{~mm}$ long; flowers successive, one open at once; sepals yellow, spotted with dark purple, not spreading, the dorsal sepal narrowly ovate, obtuse, 3-veined, 8.0-10.0 × 4.2-4.4 $\mathrm{mm}$; lateral sepals fully fused into a concave, ovate, obtuse synsepal, with a rounded concavity close to the base, 4-veined, 9.0-10.0 × 4.2-4.4 mm; petals yellow, heavily tainted with dark purple below the middle, narrowly laceolate, somewhat sigmoid, acute, pubescent bellow the middle, in natural position conspicuously recurved apically, 9.0-9.5 × 2.0-2.5 $\mathrm{mm}$; lip dark purple, obtrapezoid, depressed in the middle, with erect lateral lobes, rugose, with warts on the margins, column yellow, white apically, terete, apically arcuate, covered by minute papillae, with a pair of retrorse, arm-like, pubescent, apical lobes, $0.7 \mathrm{~mm}$ long, with a short column foot, 3.7-3.9 $\times 1.5$ $\mathrm{mm}$. Anther and stigma apical; rostellum conspicuous, erect, triangular; pollinia 2, narrowly ovoid, joint by a drop-like viscidium.

Eponymy: The name honors Carlyle Luer who described this unique species for the first time.

Additional specimens: Colombia. Valle del Cauca: Dagua, El Queremal, creciendo en talud de carretera. January 20, 1980. I. Guarín 61 (COL!). El Queremal, $\mathrm{Km} 52$ via Antigua Cali-Buenaventura, casa propiedad Napoleon Hoyos, 1400-1500 m elevation. April 20, 2011. J. Home 166 (CUVC!). El Queremal, remnant cloud forests at $1,500 \mathrm{~m}$ elevation, temperature 20 ${ }^{\circ}$ C. August 10, 2014. L. Rodríguez-Martínez 221 (CUVC!). El Queremal, remnant cloud forests at 1,500 

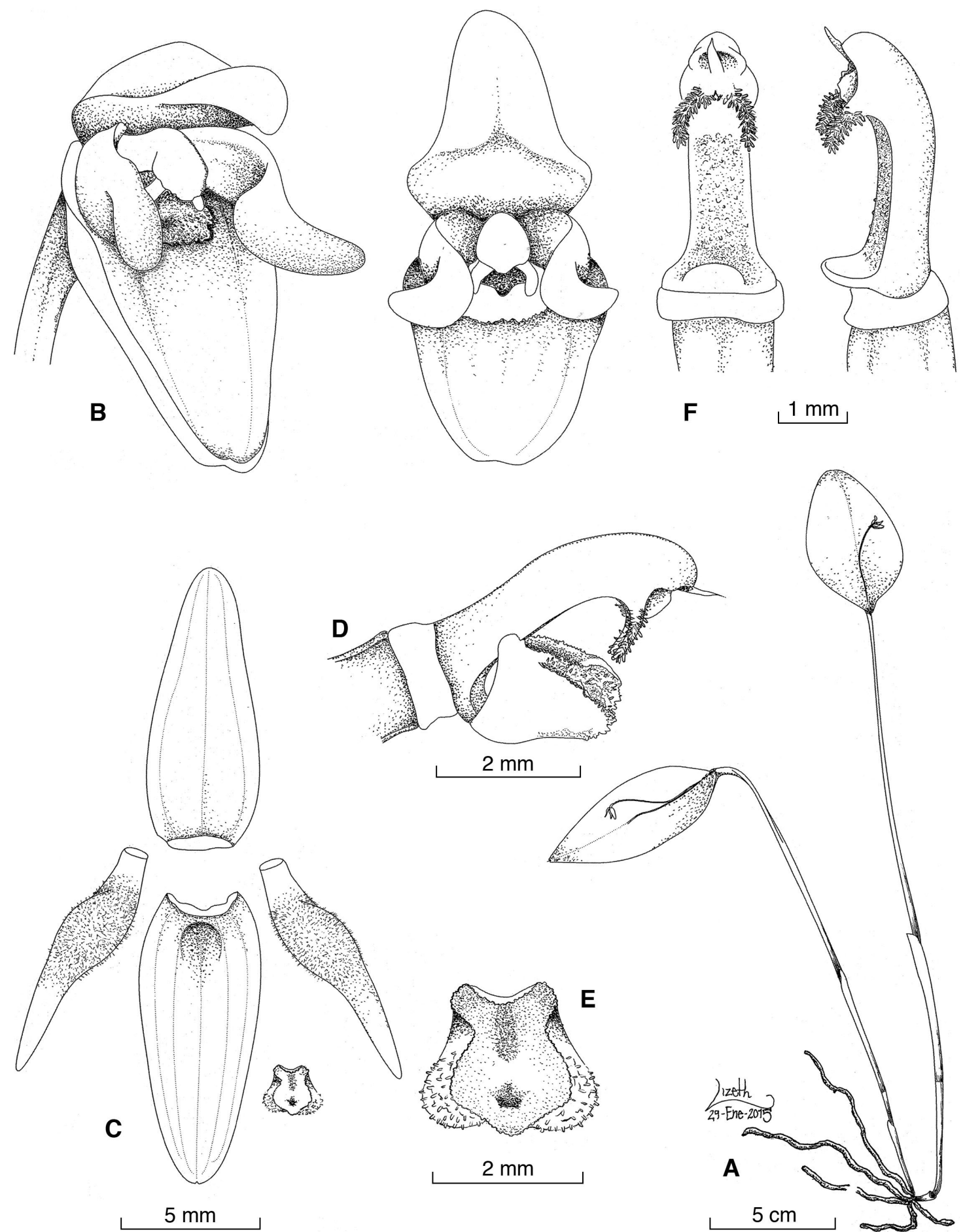

E

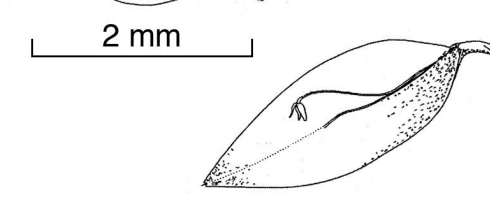

Figure 3. Pleurothallis lueriana Karremans \& Rodr.-Mart. A. Habit. B. Flower. C. Dissected perianth. D. Column and lip in lateral view. E. Lip. F. Column in ventral and side view. Illustration by L. Rodríguez-Martínez based on the holotype. 
m elevation, temperature $20^{\circ} \mathrm{C}$. August 10, 2014. L. Rodríguez-Martínez 222 (VALLE!). Without collection data, obtained from Orquídea del Valle, Calí, Colombia, cultivated by James Hamilton at Petite Plaisance, Valley Ford, CA, 1 June 2002. C. Luer 20136 (MO, holotype of $P$. jimii; illustration of type!). Without collection data, flowered in cultivation on the 22 of November 2013 at the Jardín Botánico José Celstino Mutis, CEPACOrquídeas BG-101442, J. Valencia 2055 (JBB!).

DistriBution AND ECOLOGY: It is currently known only from El Queremal, Dagua municipality, in the Valle del Cauca, Colombia, at elevations around $1500 \mathrm{~m}$. It is found as an epiphyte on the side of the old CaliBuenaventura road in the western Andes.

This species had been previously described as Pleurothallis jimii (Luer 2004), nevertheless, it was simultaneously transferred to the generic name Ancipitia, invalidating both names. The alternative names Pleurothallis jimii and Ancipitia jimii (Luer 2004) are invalid under article 36.2 of the ICN-2012, which reads "When, on or after 1 January 1953, two or more different names based on the same type are proposed simultaneously for the same taxon by the same author (so-called alternative names), none of them is validly published". Although within the publication the two names appeared under different headings, these should be treated as chapters of the same publication and not as individual publications as the author name [Carlyle A. Luer] only appears below the full title "Pleurothallis subgenus Acianthera and three allied subgenera. A second century of new species of Stelis of Ecuador. Epibator, Ophidion, Zootrophion..." on the title page, which is followed by a contents page, citing the mentioned headings. Instead of validating $P$. jimii we opt to describe the species once again because it was originally based on a single specimen from cultivated material without specific locality data, and we prefer at this time to select a specimen of known origin as holotype, several accompanying paratypes with locality data, and which are all accessible for Colombian students.

Amongst the species of Pleurothallis subgen Ancipitia, P. lueriana is immediately distinguished by the thick, dark purple, obtrapezoid lip, with erect, warty lobes, and the pair of conspicuous, apical, armlike, pubescent lobes on the column.
Pleurothallis queremalensis Rinc.-Useche, Rodr.Mart. \& Karremans, sp. nov. (Fig. 4, 5d).

TYPE: Colombia. Valle del Cauca: Municipio de Dagua, El Queremal, remnant cloud forest, $1850 \mathrm{~m}$, 6 July 2013, L. Rodríguez.-Martínez \& C.RincónUseche 092 (holotype: VALLE!).

Diagnosis: Pleurothallis queremalensis is somewhat similar to P. phratria Luer \& Hirtz but can be easily distinguished by the narrowly ovate dorsal sepal (vs. elliptic), the red, lanceolate petals with the margins serrulate (vs. purple, linear-oblong and margin entire), and the non-apiculate lip (vs. apiculate).

Plant epiphytic, herbaceous, erect, to $12 \mathrm{~cm}$ long; Roots thin, flexuous, $1 \mathrm{~mm}$ wide; ramicauls erect, thin, cylindrical, about 3-4 cm long, $1 \mathrm{~mm}$ wide, covered by two loose, papyraceous bracts at the base, about $1.5 \mathrm{~cm}$ long each; leaf apical on the ramicaul, shortly petiolate, coriaceous, narrowly elliptic to lanceolate, apex emarginate, mucronate, the margins shortly revolute, purple on the apical half of the adaxial surface and the whole abaxial surface, 8.3-8.4 × 1.5$1.6 \mathrm{~cm}$. Inflorescence racemose, $5 \mathrm{~cm}$ long, with at least two, simultaneous flowers, pendulous due to the weight of the flowers; peduncle $4 \mathrm{~cm}$ long, cylindrical, floral bract loose, acute, $6.5 \mathrm{~mm}$ long, ovary $4 \mathrm{~mm}$ long; flowers non-resupinate, sepals brownish-orange, translucent, petals bright red, lip yellowish; dorsal sepal narrowly-ovate, acute, glabrous, 3-nerved, $1.5 \times 0.4 \mathrm{~cm}$; lateral sepals completely fused into a synsepal, ovate, acute, 6-nerved, 1.3-1.5 × 1.0-1.2; petals lanceolate, subfalcate, acute, 3-nerved, glabrous except for the serrulate margins, $1.2 \times 0.3 \mathrm{~cm}$; lip suborbicular, obtuse, $4.0 \times 4.5 \mathrm{~mm}$, in natural position the basal margins of the blade are somewhat incurved, hinged to the column foot by a shortly deflexed base; column yellow, straight, terete, $3.0-3.5 \times 1.0 \mathrm{~mm}$; anther and stigma apical; rostellum conspicuous, ligulate; pollinia 2, ovoid, united by a drop-like viscidium.

EтумоLоgy: The name refers to the locality where the type specimen of this species was found, El Queremal in the Municipio de Dagua, Valle del Cauca, Colombia.

Distribution AND ECOLOGY: Pleurothallis queremalensis is known so far from the remnant cloud forest in 


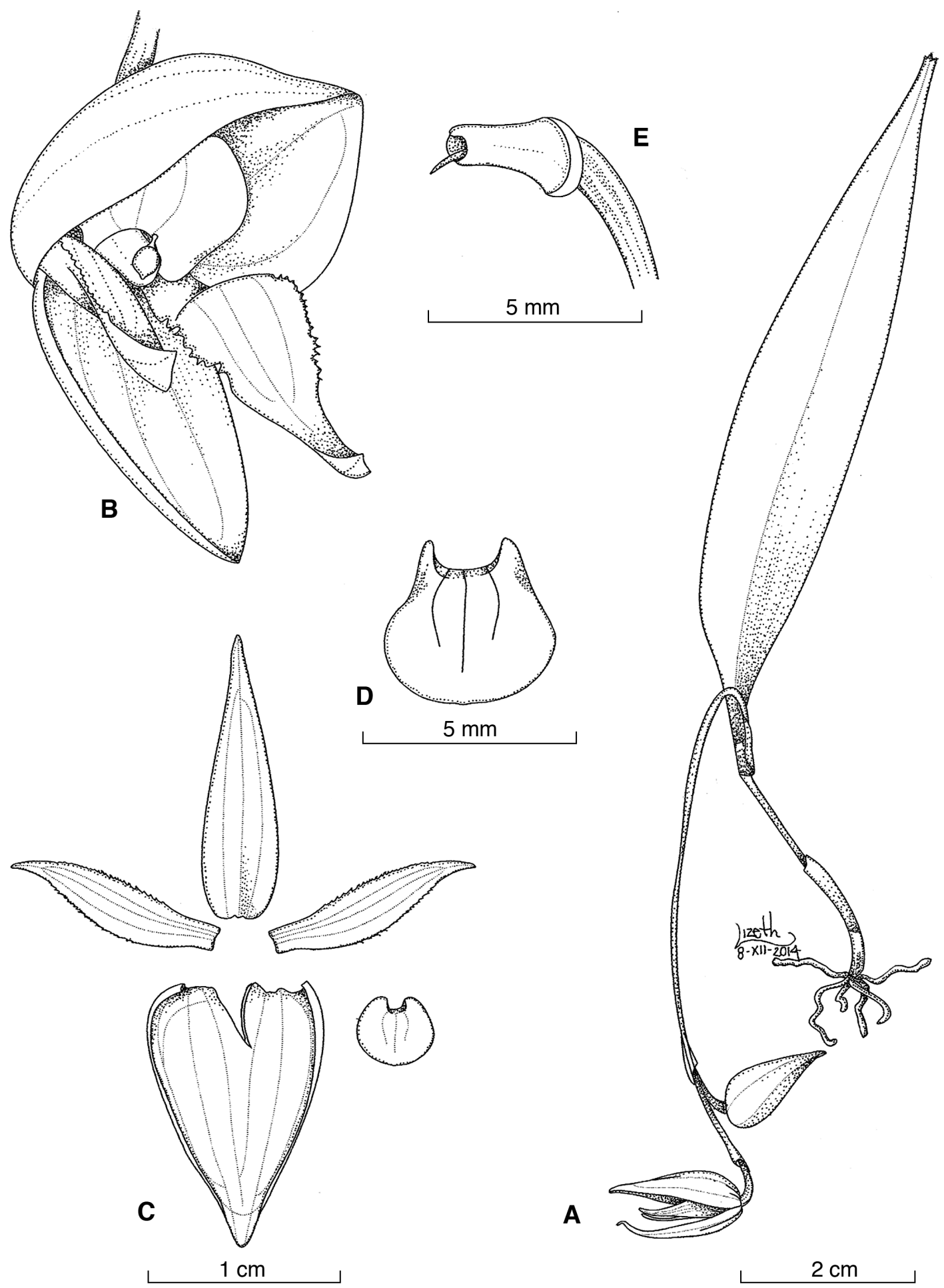

FIgure 4. Pleurothallis queremalensis Rincón-Useche, Rodr.-Mart. \& Karremans. A. Habit. B. Flower. C. Dissected perianth, with the lip extended. D. Lip in natural position. E. Column. Illustration by L. Rodríguez-Martínez based on the holotype. 

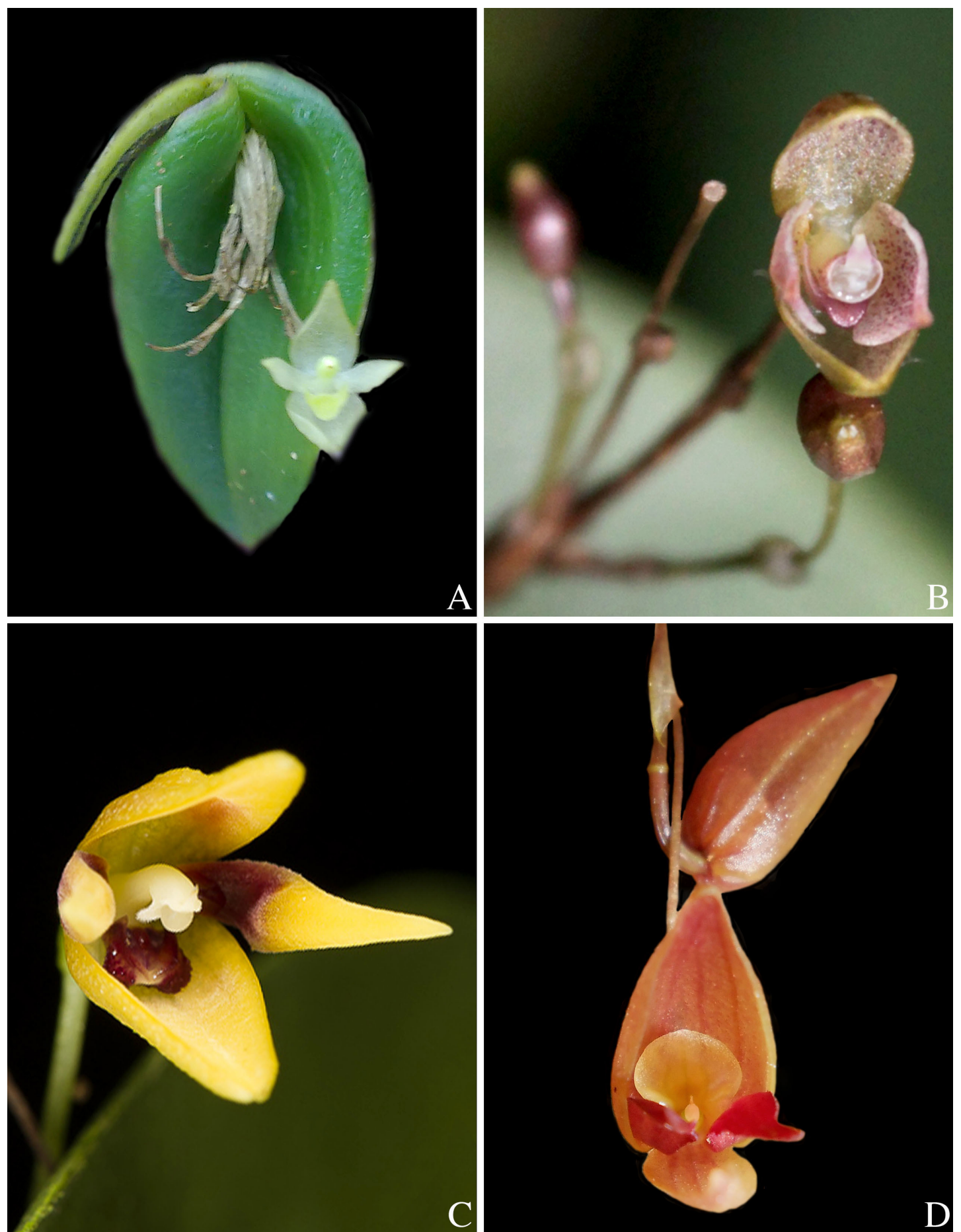

Figure 5. A. Pleurothallis indecora Rodr.-Mart. \& Karremans. B. Pleurothallis juvenilis Rodr.-Mart. \& Karremans. C. Pleurothallis lueriana Karremans \& Rodr.-Mart. D. Pleurothallis queremalensis Rincón-Useche, Rodr.-Mart. \& Karremans. Photographs by L. Rodríguez-Martínez \& C. Rincón-Useche (A, B, D) from the plants that served as type, and S. Vieira-Uribe (C) from an un-vouchered specimen. 
the western Andes in the municipality of Dagua, corregimiento of El Queremal, department of Valle del Cauca, Colombia. It was observed growing as an epiphyte on Tibouchina sp. (Melastomataceae) trees in a fragmented cloud forest at 1800-1900 m elevation. A single specimen was observed in flower in July.

\section{Pleurothallis queremalensis belongs \\ to Pleurothallis sect. Pleurothallis subsect.} Macrophyllae-Racemosae (Luer 1999), of which Pleurothallis lindenii Lindl. is probably the most representative species. The novelty is closely related to Pleurothallis cachabensis Luer \& Hirtz, P. cajamarcae Schltr. and P. tiarata Luer \& Hirtz, but the most closely related species is probably $P$. phratria. Pleurothallis queremalensis can be distinguished from the latter by the narrowly ovate dorsal sepal (vs. elliptic), the red, lanceolate petals with the margins serrulate (vs. purple, linear-oblong and margin entire), and the suborbicular, non-apiculate lip (vs. cordate, apiculate).

ACKNOWLEDGMENTS. This manuscript was prepared as part of a dedicatory issue commemorating the 95th birthday of Carl Luer, who's extensive work on the Pleurothallidinae is the basis for most current studies in the subtribe, including the present. Sebastian Vieira Uribe is thanked for allowing us to reproduce his photographs. Mike Grayum is thanked for his insights on the interpretation of the nomenclatural issues dealt with here. Mark Wilson kindly commented on earlier versions of this manuscript. Two anonymous reviewers are thanked for their comments. The Instituto de Ciencias Naturales de la Universidad Nacional de Colombia, sede Bogotá is thanked for the help in accessing the collections at COL. This study could not have been carried out without the help of professor Julio Betancur.

\section{LITERATURE CITED}

Hágsater, E., Reina-Rodríguez, G. A. \& RodríguezMartínez, L. (2015). Epidendrum chicalorum Hágsater, Reina-Rodr. \& Rodr.-Mart. Icones Orchidacearum, 15(1), t. 1512.

Hágsater, E., Santiago Ayala, E. \& RodríguezMartínez, L. (2016). Epidendrum lasiostachyum (Orchidaceae): a new Colombian species of the Epidendrum macrostachyum group. Lankesteriana, 16(1), 27-37. Doi: http://dx.doi.org/10.15517/ lank.v16i1.23621

Luer, C. A. (1986). Icones Pleurothallidinarum III. Systematics of the genus Pleurothallis (Orchidaceae). Monographs in Systematic Botany from the Missouri Botanical Garden, 20, 1-107.

Luer, C. A. (1989). Icones Pleurothallidinarum VI. Systematics of Pleurothallis subgenus Ancipitia, subgenus Scopula and Trisetella (Orchidaceae). Monographs in Systematic Botany from the Missouri Botanical Garden, 31.

Luer, C. A. (1999). Icones Pleurothallidinarum XVIII: Systematics of Pleurothallis subgen. Pleurothallis, sect. Pleurothallis, subsect. Antenniferae, subsect. Longiracemosae, subsect. Macrophyllae-
Racemosae, subsect. Perplexae, subgen. Pseudostelis, subgen. Acuminatia. Monographs in Systematic Botany from the Missouri Botanical Garden, 76, 1-182.

Luer, C. A. (2004). Icones Pleurothallidinarum XXVI. Pleurothallis subgenus Acianthera and three allied subgenera. A second century of new species of Stelis of Ecuador. Epibator, Ophidion, Zootrophion. Monographs in Systematic Botany from the Missouri Botanical Garden, 95, 1-265.

Pérez-Escobar, O. A., Kolanowska, M. \& RincónUseche, C. (2012). A New Species of Lepanthes (Pleurothallidinae, Orchidaceae) from Colombia. Systematic Botany, 38(2), 316-319.

Rodríguez-Martínez, L. \& Blanco, M. (2015). A new species of Camaridium (Orchidaceae: Maxillariinae) from the cloud forests of Colombia. Phytotaxa, 222(1), 61-66.

Rodríguez-Martínez, L., Rincón-Useche, C. \& Karremans, A. P. (2015). A New Pleurothallis from Colombia, with a Note on Ancipitia and Colombiana (Orchidaceae: Pleurothallidinae). Systematic Botany, 40(1), 75-78. 